\section{Hawke fights on second front \\ Canberra}

THE Australian Labor government seems to have successfully contained the damage that might have been done by last month's visit to Washington by $\mathrm{Mr} \mathrm{R}$. J. (Bob) Hawke, the Prime Minister. The issue is $\mathrm{Mr}$ Hawke's widely reported reversal of an earlier decision to provide logistical support for two US MX missile tests to be held this year in the Tasman Sea, off Australia's east coast. The government had feared that internal faction fights would cause trouble. Stiffer tests of consensus are to come, however. Mr Hawke has come under continuing pressure from the United States to strengthen US-Australian bilateral defence agreements and to promote the growing isolation of neighbouring New Zealand, following that country's refusal of port facilities to a nuclear-capable US warship earlier this year. The three countries are bound together militarily by the ANZUS treaty. On 4 March, however, $\mathrm{Mr}$ Hawke announced that the next ANZUS council meeting scheduled for July had been indefinitely postponed. Strictly speaking, under the treaty the three countries are obliged only to "consult together" in time of threat. But in practice ANZUS has been the formal basis for the US security guarantee to Australia and New Zealand for thirty-three years. Cancellation of the council meeting signals its likely imminent demise.

Mr Hawke's difficulties began immediately before his departure from Australia on 2 February for meetings in the United States with President Reagan and Secretary of State George Schultz, when he was reported to have agreed, without consulting his full cabinet or caucus, to provide facilities for US monitoring of the MX splashdown area.

The agreement would have fulfilled an undertaking by former prime minister $\mathrm{Mr}$ Malcolm Fraser, and would have made it possible to test the accuracy of the fourstage missile over its full range of 14,000 $\mathrm{km}$, rather than over the shorter Vandenberg-Kwajalein range. With ten 350-kiloton warheads, the accuracy of the MX over a distance of $7,000 \mathrm{~km}$ is approximately 90 metres using NAVSTAR guidance.

Under pressure from the Labor Party's left wing, Mr Hawke cabled from Brussels on 6 February (the day before he was due to meet President Reagan) his decision to withdraw from the tests. The switch was made to look even more humiliating by $\mathrm{Mr}$ Hawke's exhortation three weeks earlier to New Zealand Prime Minister David Lange to rescind his decision to deny the use of port facilities to the destroyer USS Buchanan if the ship were to be carrying nuclear weapons, an item of information routinely refused by the US Navy.

Despite the MX fiasco, Mr Hawke has been let off much more lightly by Washington than has $\mathrm{Mr}$ Lange. There appear to be several reasons for this. One is a desire to counter the growing influence of the Australian government's left wing, another to send a message to wavering NATO allies emboldened by Mr Lange's

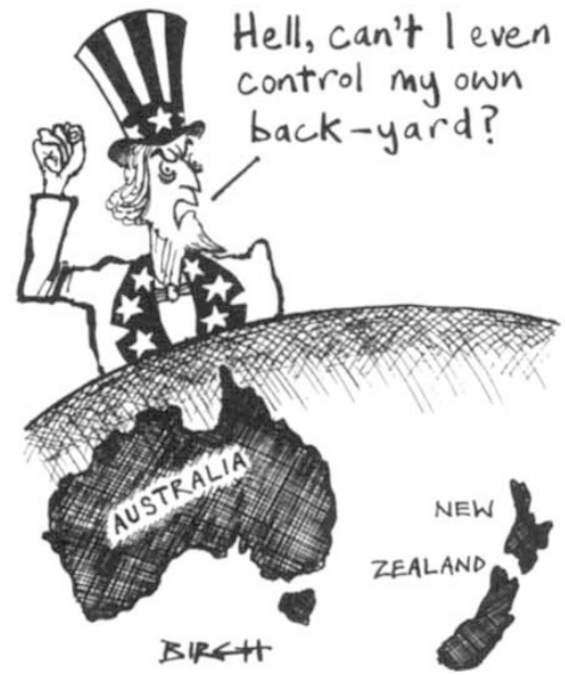

actions, and a third the importance the United States attaches to its Communications Command Control and Intelligence $\left(\mathrm{C}^{3} \mathrm{I}\right)$ bases on Australian soil.

Information about these installations is scarce and more likely to be uncovered in US publications or under the US Freedom of Information Act than through Australian
OfFICIALLY referred to as "joint USAustralian facilities, the most important US defence installations in Australia are, according to Dr Desmond Ball of the Australian National University, the following.

Naval Communications Station Harold $E$. Holt, North West Cape.

Operational since 1967, this station maintains reliable. communications with the nuclear-powered ballistic missile submarines of the US fleet patrolling the Pacific Ocean. The VLF (Very Low Frequency) facility is the largest and most powerful in the US worldwide communications system. North West Cape also has an array of high-frequency transmitters used for US military operations in the Indian and Western Pacific Oceans, as well as a ground station for the US Defense Satellite Communications Systems (DSCS). Joint Defense Space Research Facility, Alice Springs (known as Pine Gap). Operational since 1969, the facility is $19 \mathrm{~km}$ south-west of Alice Springs and consists of seven large radomes and a large computer complex. Pine Gap was originally established as part of Project Rhyolite, which involves a small number of very large

government channels, but there are thought to be more than two dozen of them.

The continued presence of these stations in Australia has become a contentious issue. Critics of the facilities at Pine Gap and Nurrungar (see below) in particular charge that whatever their value when they were commissioned, during the "deterrence"' years, they are now (or could become) part of a first-strike "counterforce" system and hence nuclear targets. This strikes at the heart of Mr Hawke's embattled strategy for peace and disarmament, a major plank of government policy.

The New Zealand government is soon to become even more isolated militarily after Mr Hawke's announcement last week that New Zealand will in future be denied the usually generous US component of the intelligence "product" formerly shared among the United States, United Kingdom, Australia and New Zealand and Canada under the 1947 UKUSA secret treaty. Practical problems of intelligence separation have arisen for the Australian government because intelligence from the "joint facilities" combines information from shared sources as well as that gathered solely by Australia. This is compounded by the presence (on secondment) of New Zealand intelligence officers in several sensitive Australian installations. $\mathrm{Mr}$ Hawke must now deal with the looming policy problems of south-west Pacific regional defence, at the same time avoiding the impression that Australia is dumping a small idealistic neighbour at the behest of the United States.

Jeffrey Sellar

\title{
US defence facilities in Australia
}

antenna-carrying signals-intelligence (SIGINT) satellites in geostationary orbit. The facility monitors a wide spectrum of Soviet and Chinese military communications and radar transmissions, allowing the mapping of the extensive Soviet earlywarning and air defence networks, as well as telemetry data transmitted during Soviet ballistic missile tests. This is the principal means of monitoring Soviet missile developments, and hence Soviet compliance with the strategic arms agreements. Joint Defense Space Communications Station, Woomera (known as Nurrungar). This is within the Woomera restricted area, $480 \mathrm{~km}$ north-west of Adelaide, and with Buckley, Colorado, is one of the two ground stations for the US satellite earlywarning system. Nurrungar provides a realtime link between the North American Air Defense Command (NORAD), Strategic Air Command (SAC), the national military command system and the satellite earlywarning system. Data are derived from infrared, charged particle and radiation sensors aboard the geostationary satellites of Program 647 of the Defense Support Program (DSP), which detect missiles shortly after lift-off.
Jeffrey Sellar 